Historia Slavorum Occidentis

2020, nr $2(25)$

ISSN 2084-1213

DOI: $10.15804 /$ hso200204

Artur Dęisski (Poznań)

Hanna KóčKa-Krenz (Poznań)

ORCID: 0000-0002-2082-8177

\title{
Wpływy północne (skandynawskie) i zachodnie w państwie pierwszych Piastów*
}

Słowa kluczowe: Wielkopolska, Kujawy, Skandynawia, import, kontakty kulturowe, wczesne średniowiecze, Europa Zachodnia, architektura przedromańska

Keywords: Wielkopolska/Greater Poland, Kujawy/Cuiavia, Scandinavia, imports, cultural contacts, early Middle Ages, western Europe, pre-Romanesque architecture

Abstract: The article deals with the issues concerning an extent and nature of cultural contacts between the early Piasts' populations and Scandinavia, as reflected by archaeological evidence. The contacts with Carolingian and Ottonian cultures were recorded in sociotopography of leading fortified settlements and also in reception of secular and sacral forms of pre-Romanesque architecture.

Ślady wpływów skandynawskich, uchwytne w materiale archeologicznym rejestrowanym na obszarach leżących na południe od Bałtyku, niejednokrotnie już zaprzątały uwagę badaczy zajmujących się okresem wczesnego średniowiecza ${ }^{1}$. Stanowiska

* Praca naukowa finansowana w ramach programu Ministra Nauki i Szkolnictwa Wyższego pod nazwą „Narodowy Program Rozwoju Humanistyki” w latach 2014-2020 - projekt nr 0040/ NPRH3/H11/82/2014.

1 J. Żak, „Importy” skandynawskie na ziemiach zachodniostowiańskich od IX do XI wieku, Poznań 1967; tenże Problem „importów” skandynawskich w dorzeczu Odry i Wisty w IX, X 
z wyrobami wskazującymi na pochodzenie bądź inspirację wytwórczością ludów Skandynawii grupują się jednak przede wszystkim na terenie województwa zachodniopomorskiego, pomorskiego i warmińsko-mazurskiego ${ }^{2}$. Znaleziska tego rodzaju stosunkowo licznie rejestrowano także na obszarze Wielkopolski, a więc w ścisłym centrum formującego się państwa Piastów. Pod względem liczebności takich przedmiotów region ten ustępuje jedynie Pomorzu Zachodniemu ${ }^{3}$. Materialne ślady skandynawskich wpływów kulturowych nieco mniej licznie odnotowywano na obszarze Kujaw, przy czym niektóre z nich były dość spektakularne.

Archeologiczne świadectwa kontaktów ze Skandynawią można podzielić na dwie zasadnicze kategorie. Pierwszą z nich stanowią wytwory kultury materialnej rejestrowane na stanowiskach, zarówno w obrębie osad, jak i cmentarzysk. Przedmioty o proweniencji północnej odnotowywane bywają również dość licznie w skarbach. Do drugiej kategorii wypada zaliczyć świadectwa nieco mniej wyraźne, związane ze sferą duchowości i wierzeń, dziś uchwytne przede wszystkim w postaci specyficznych cech obrządku pogrzebowego.

Charakteryzując wielkopolski zespół znalezisk archeologicznych o skandynawskim pochodzeniu należy przywołać przede wszystkim Ostrów Lednicki, gm. Łubowo. Odkryty w sąsiedztwie wyspy unikatowy zespół militariów zawierał liczne elementy stanowiące materialne świadectwo wpływów północnych. Pomimo że zbiór ten interpretowany jest zwykle jako materialne świadectwo starć zbrojnych lub nawet konkretnej bitwy z wojskami księcia Brzetysława I, to wskazuje się również rzemieślnicze zastosowanie części odkrytych tam przedmiotów, wiążąc je z budową bądź naprawa-

i XI wieku, [w:] Studia nad etnogenezą Stowian i kultura Europy wczesnośredniowiecznej, red. G. Labuda, S. Tabaczyński, Wrocław-Warszawa-Kraków-Gdańsk-Łódź 1988, s. 179-187; M. Wołoszyn, Ze studiów nad obecnością ruska i skandynawska na ziemiach polskich $w$ X-XII w., [w:] Świat Stowian wczesnego średniowiecza, red. M. Dworaczyk, A.B. Kowalska, S. Moździoch, M. Rębkowski, Szczecin-Wrocław 2006, s. 59-613; M. Bogacki, A. Janowski, Ł. Kaczmarek Wikingowie w Polsce? Zabytki skandynawskie z ziem polskich, Gniezno-Szczecin 2019.

2 M. Kara, Wczesnośredniowieczny grób uzbrojonego kupca w miejscowości Ciepłe na Pomorzu Gdańskim w świetle ponownej analizy chronologicznej, [w:] Kraje stowiańskie w wiekach średnich. Profanum i sacrum, red. H. Kóčka-Krenz, W. Łosiński, Poznań 1998, s. 505-524; M.F. Jagodziński, Truso. Między Weonlandem a Witlandem, Elbląg 2010; J. Wojtkowiak, Skandynawskie wplywy kulturowe $w$ Wolinie (IX-XI w.), Wrocław 2012.

3 A. Krzewicka Wczesnośredniowieczne znaleziska $w$ typie skandynawskim $z$ terenu Polski, Kraków 2013, Maszynopis pracy magisterskiej, https://www.academia.edu/4300467/Wczesnośredniowieczne_znaleziska_w_typie_skandynawskim_z_terenu Polski [dostęp z dnia 29 III 2019]. 
mi mostów ${ }^{4}$. Zdaniem części badaczy również cały zespół militariów zdeponowanych w wodzie może być nawiązaniem do obyczajów skandynawskich ${ }^{5}$. Ten stosunkowo różnorodny zbiór nie ułatwia jednak interpretacji, zwłaszcza w kwestii pochodzenia poszczególnych jego elementów. W przypadku samych tylko toporów, w zespole liczącym ponad 140 egzemplarzy za „skandynawskie” uznano od kilku do kilkudziesięciu sztuk ${ }^{6}$. Wobec powyższego uwagę badaczy przyciągają zwłaszcza znaleziska broni drzewcowej, wśród których dość precyzyjnie wskazano na skandynawską proweniencję co najmniej 21 z 62 grotów $^{7}$. Co istotne, interpretację taką oparto nie tylko na formie przedmiotów, ale również na charakterystycznym zdobnictwie części z nich, typowym dla stylu Ringerike. Oczywiście przywołanymi tu militariami niekoniecznie musieli się posługiwać Skandynawowie, przynajmniej część z nich należała do Słowian lub najemników pochodzących z innych krajów ${ }^{8}$. Północne wpływy dostrzeżono również na niektórych z ozdób odkrytych na Ostrowie Lednickim. Z badań podwodnych pochodzi pojedyncza srebrna tarczka $\mathrm{z}$ bogatą dekoracją i otworami na nity, bezspornie uznana za „charakterystyczną dla kultury wikińskiej”. Pogłębiona analiza znaleziska nie rozstrzygnęła ostatecznie jego pierwotnej funkcji, wskazywano m.in. na okucie rzędu końskiego lub ozdobną aplikację stroju, podkreślając jej paradny, luksusowy charakter ${ }^{10}$. Nieco więcej wątpliwości wzbudziła natomiast trójkątna, niewielka tarcza

4 W. Tokarski, Militaria - broń miotająca, obuchowa i drzewcowa, oraz elementy rzędu końskiego i oporządzenia jeździeckiego, [w:] Wczesnośredniowieczne mosty przy Ostrowie Lednickim, t. I: Mosty traktu gnieźnieńskiego, red. Z. Kurnatowska, Lednica-Toruń 2000, s. 77-103, por. s. 88-89; G. Wilke, Próba interpretacji podwodnych odkryć militariów przy rezydencji pierwszych Piastów na Ostrowie Lednickim, [w:] Świat Stowian wczesnego średniowiecza, s. 443-455; G. Wilke, Groty broni drzewcowej z Ostrowa Lednickiego, [w:] Broń drzewcowa i uzbrojenie ochronne $z$ Ostrowa Lednickiego, Giecza i Grzybowa, red. P. Sankiewicz, A.M. Wyrwa, Lednica 2018, s. 33-87, por. s. 73 n.

5 W. Duczko, Viking Rus. Studies on the Presence of Scandinavians in Eastern Europe, Boston 2004, s. 251.

6 J. Górecki, Gród na Ostrowie Lednickim na tle wybranych ośrodków grodowych pierwszej monarchii piastowskiej, Lednogóra 2001, s. 136 n.; A. Krzewicka, Wczesnośredniowieczne, s. 44-45; P. Kotowicz, Analiza kolekcji toporów średniowiecznych, [w:] Topory średniowieczne z Ostrowa Lednickiego $i$ Giecza, red. P. Sankiewicz, A.M. Wyrwa, Lednica 2013, s. 44-100, por. s. 69-70.

7 G. Wilke, Groty broni drzewcowej z Ostrowa Lednickiego, [w:] Broń drzewcowa i uzbrojenie ochronne, s. 33-87, por. s. 54-62.

8 W. Duczko, Wikingowie i wczesnośredniowieczna Polska, [w:] Swoi i obcy w kulturze średniowiecza, red. M. Brzostowicz, M. Przyby1, J. Wrzesiński, Poznań-Ląd 2011, s. 61-69, por. s. 66. 9 J. Górecki, Gród na Ostrowie, s. 123.

10 M. Kara, J. Wrzesiński, Ozdobne okucie z grodziska na Ostrowie Lednickim, [w:] Stowianie 
wykonana ze złota, zdobiona motywem przeplatanego trójliścia. Upatrywano w niej zarówno wyrobu skandynawskiego, jak i frankońskiego ${ }^{11}$. Ostatnio wskazano także na możliwe powiązania przedmiotu $\mathrm{z}$ kultem boga Thora, nie rozstrzygając jednakże tej kwestii w sposób ostateczny ${ }^{12}$. Pośród odkrytych na grodzie lednickim zabytków o możliwym północnym pochodzeniu badacze wymieniają jeszcze fragment szpili, zawieszkę w kształcie krzyżyka i fragment zapinki typu Terslev ${ }^{13}$. W pobliżu grodu $\mathrm{w}$ Łeknie, gm. Wagrowiec, zarejestrowano dobrze zachowany fragment trzewika pochwy miecza ${ }^{14}$. Przedmiot zdobiony był w stylu Borre. Znaleziska z osad uzupełniają odkrycia dokonane w miejscowości Luboń, pow. poznański i w samym Poznaniu. W obrębie osady lubońskiej odkryto fragment grotu włóczni typu E wg Petersena uznany za: „niewątpliwy wytwór skandynawski” ${ }^{15}$. Z kolei z Poznania pochodzi ujawniony w sąsiedztwie palatium książęcego szklany pion do gry w hnefatafl ${ }^{16}$. Omawiając znaleziska z osad warto wspomnieć o przedmiotach drewnianych, bądź kościanych zdobionych w stylu pierścieniowo-łańcuchowym o wyraźnych nawiązaniach skandynawskich ${ }^{17}$. WWielkopolsce takie wyroby rejestrowano na stanowiskach w Gnieźnie, Grzybowie, Gieczu, Łeknie, Santoku, Lądzie i na Ostrowie Lednickim ${ }^{18}$.

i ich sąsiedzi we wczesnym średniowieczu, red. M. Dulinicz, Warszawa-Lublin 2003, s. 393-405 .

11 W. Szymański, Kontakty handlowe Wielkopolski w IX-XI w., Poznań 1958, s. 59; J. Kostrzewski, Kultura prapolska, Warszawa 1962, s. 316; P. Urbańczyk, Archeologiczne świadectwa obecności „Skandynawów” w państwie Bolesława Chrobrego, [w: ] Wikingowie w Polsce? Zabytki, s. 127-144.

12 W. Duczko, J. Wrzesiński, Bóg Skandynawów na Ostrowie Lednickim? Próba interpretacji znaleziska złotej blaszki z trykwetra, [w:] Gemma gemmarum. Studia dedykowane Profesor Hannie Kóčce-Krenz, red. A. Różański, cz. 2, Poznań 2017, s. 1187-1198.

13 M. Kara, Sity zbrojne Mieszka I. Z badań nad składem etnicznym, organizacja i dyslokacja drużyny pierwszych Piastów, Kronika Wielkopolski 62 (1992), nr 3, s. 33-47, por. s. 37.

14 A.M. Wyrwa, A. Janowski, Dolne okucie pochwy miecza z przedstawieniem ludzkiej twarzy z Łekna (st. Ł5), Fontes Archaeologici Posnanienses 50 (2014), s. 323-346.

15 J. Żak, „Importy” skandynawskie, s. 293-294.

16 A. Dębski, Katalog wystawy „Ostrów Tumski w świetle badań archeologicznych”, [w:] Tu się Polska zaczęła..., red. H. Kóčka-Krenz, Poznań 2007, Płyta CD, nr kat. 73.

17 W. Duczko, Obecność skandynawska na Pomorzu i słowiańska w Skandynawii we wczesnym średniowieczu, [w: ] Salsa Cholbergensis. Kołobrzeg w średniowieczu, red. L. Leciejewicz, M. Rębkowski, Kołobrzeg 2000, s. 23-44, por. s. 29.

18 M. Brzostowicz, Gród wczesnośredniowieczny w Lądzie nad Wartą w świetle badań archeologicznych, [w:] Ląd nad Warta, red. M. Brzostowicz, H. Mizerski, J. Wrzesiński, Poznań 2005, s. 47-60; W. Chudziak, R. Kaźmierczak, Zdobnictwo przedmiotów drewnianych z Żóttego na 
W przywoływanej miejscowości Luboń odkryto ponadto cmentarzysko wczesnośredniowieczne z ponad dwudziestoma grobami szkieletowymi. Na jego zniszczonej części zarejestrowano liczne militaria o skandynawskiej proweniencji, w tym topór typu Lunow wg P. Paulsena. Przez część badaczy cmentarzysko interpretowane jest jako miejsce pochówku konnych drużynników książęcych pochodzących ze Skandynawii ${ }^{19}$. Lista cmentarzysk z uchwytnymi wpływami północnymi zarejestrowanych na terenie Wielkopolski jest jednak dłuższa. Na nekropoli położonej w miejscowości Łubówko, pow. Gniezno odkryto żelazny grot włóczni oraz ostrogę odmiany 1. typu I. Obydwa przedmioty wykazują wyraźne wpływy skandynawskie, choć zmarłych spoczywających w odsłoniętych tam grobach uznano za przedstawicieli lokalnej społeczności ${ }^{20}$. Z kolei w miejscowości Skokówko, pow. Gostyń, odsłonięto grób wyposażony m.in. w grot włóczni typu $\mathrm{K}$ wg J. Petersena oraz topór. Militaria te uznano za wyroby północne, zaś sam pochówek za miejsce spoczynku konnego woja skandynawskiego ${ }^{21}$. Być może podobny grób drużynnika książęcego pochodzącego z północy uchwycono także w Ostrowążu, pow. koniński, jednak zaginione wyposażenie pozostawia powyższą interpretację w sferze domysłów ${ }^{22}$. W kontekście omawianego problemu uwagę zwraca również cmentarzysko w Dziekanowicach, gdzie zarejestrowano sześć grobów uznanych za komorowe, w tym jeden zawierający naszyjnik złożony z kaptorg i pojedynczej zawieszki krzyżowatej ${ }^{23}$.

Większej liczby przedmiotów pochodzących ze Skandynawii dostarczają skarby ${ }^{24}$. Na obszarze dzisiejszego Drezdenka, gm. loco, odkryto zespół monet i srebrnych ozdób zawierający m.in. srebrny garnitur toaletowy ${ }^{25}$. Najbliższy odpowiednik tego

Pomorzu Zachodnim jako przykład tzw. pomorskiej szkoty ornamentyki skandynawsko-insularnej, Archaeologia Historica Polona 21 (2013), s. 23-25.

19 M. Kara, Sity zbrojne, s. 39.

20 J. Żak, „Importy” skandynawskie”, s. 295-297.

21 M. Kara, Z badań nad wczesnośredniowiecznymi grobami z uzbrojeniem $z$ terenu Wielkopolski, [w:] Od plemienia do państwa. Ślask na tle wczesnośredniowiecznej Stowiańszczyzny zachodniej, red. L. Leciejewicz, Wroclaw-Warszawa 1991, s. 99-120, tu s. 115.

22 M. Kara, $Z$ badań nad wczesnośredniowiecznymi grobami, s. 115.

23 Srebrny naszyjnik z kaptorgami i krzyżowata zawieszka z Dziekanowic, red. J. Wrzesiński, A.M. Wyrwa, Lednica 2015.

${ }^{24}$ W publikacji nie uwzględniono licznych znalezisk numizmatów, stanowiących odrębną problematykę znacznie przekraczającą ramy przyjęte w niniejszym opracowaniu; por. J. Slaski, S. Tabaczyński, Wczesnośredniowieczne skarby srebrne Wielkopolski. Materiaty, Warszawa-Wrocław 1959, s. $11 \mathrm{n}$. 25 J. Slaski, S. Tabaczyński, Wczesnośredniowieczne skarby, s. 13; J. Żak,Importy” skandynawskie, s. 259-260. 
dość nietypowego znaleziska na naszych ziemiach pochodzi z Gotlandii. W innym skarbie, na który natrafiono w Dzierżnicy, gm. Dominowo, znajdował się fragment zapinki kolistej ${ }^{26}$. Dwa dalsze, podobne egzemplarze odkryto w skarbach z Jarocina, gm. loco, i Raszew, gm. Żerków. Analogie do wszystkich trzech wymienionych okazów stwierdzono m.in. na Jutlandii i Zelandii. W depozycie z Gralewa, gm. Santok, zarejestrowano fragmenty trzech innych zapinek kolistych oraz jednego lub dwóch ułamków wisiorków krzyżowatych ${ }^{27}$. Zapinki reprezentujące warianty z motywem stylizowanych figur zwierzęcych oraz ze zdobnictwem plastycznym pozwalają na wskazanie podobnych okazów w skarbach duńskich i szwedzkich, a pierwsze z wymienionych - również norweskich. Z kolei analogiczne wisiorki odnotowywano na Jutlandii, Zelandii i Gotlandii. Podobny wisiorek krzyżowaty zarejestrowano także w Kątach, gm. Murowana Goślina. W odkrytym w powiecie słubickim skarbie, znanym jako Lisów, bądź Lisówek odkryto w całości zachowaną szpilę srebrną, fragment naramiennika oraz wisiorek krzesiwkowaty ${ }^{28}$. Dwa pierwsze z przedmiotów mają odpowiedniki na Gotlandii, z kolei zbliżone, choć nie identyczne wisiorki często rejestrowano na obszarze Upplandu, rzadziej na obszarze Danii i Norwegii. W skarbie odkrytym w Łękach Wielkich, gm. Kamieniec, zidentyfikowano kolejny fragment zapinki kolistej ${ }^{29}$, zaś w depozycie odkrytym na gruntach wsi Obra, względnie Nowa Obra w gminie Wolsztyn, odnotowano wisiorek kolisty, znajdujący odpowiedniki na Gotlandii i w Skaniii ${ }^{30}$. Z kolei z Rakoniewic, gm. loco, znany jest fragment skandynawskiego naramiennika ${ }^{31}$. Przegląd ozdób pochodzenia skandynawskiego odkrywanych w skarbach zakończyć należy depozytem z Zalesia, pow. Konin, w którym zidentyfikowano ułamki wisiorków kolistych oraz szpili pierścieniowatej, o analogiach gotlandzkich ${ }^{32}$.

26 J. Slaski, S. Tabaczyński, Wczesnośredniowieczne skarby, s. 19-20, 25-26, 57-58; J. Żak, "Importy" skandynawskie, s. 195-200.

27 J. Żak, „Importy” skandynawskie, s. 195-200, 203-205, 213-216; A. Krzewicka, Wczesnośredniowieczne, s. 41.

28 J. Slaski, S. Tabaczyński, Wczesnośredniowieczne skarby, s. 34-37; J. Żak, „Importy” skandynawskie, s. 208-209, 217-218.

29 J. Slaski, S. Tabaczyński, Wczesnośredniowieczne skarby, s. 38; J. Żak, „Importy” skandynawskie, s. 195-200.

30 J. Slaski, S. Tabaczyński, Wczesnośredniowieczne skarby, s. 44-45; J. Żak, „Importy” skandynawskie, s. 211-213.

31 J. Slaski, S. Tabaczyński, Wczesnośredniowieczne skarby, s. 56-57; J. Żak, „Importy” skandynawskie, s. 235-240.

32 J. Slaski, S. Tabaczyński, Wczesnośredniowieczne skarby, s. 72; J. Żak, „Importy” skandynawskie, s. 208-209. 
Powyższą prezentację przedmiotów wykazujących mniej lub bardziej czytelne związki ze Skandynawią uzupełnią zapewne wkrótce kolejne znaleziska. Nowych danych dostarcza również reinterpretacja starszych odkryć, jak miało to miejsce w przypadku przypomnianego ostatnio grzebienia kościanego pochodzącego z miejscowości Stroszki w pobliżu Giecza ${ }^{33}$.

W porównaniu z Wielkopolską, liczebność stanowisk archeologicznych z uchwytnymi śladami wpływów skandynawskich znanych z terenu Kujaw wydaje się dość skromna. Przywołać tu należy cmentarzysko w Brześciu Kujawskim z grobem zawierającym miecz typu $\mathrm{Z}$ wg J. Petersena ${ }^{34}$ oraz odkryte w ostatnich latach cmentarzysko w Bodzi, gm. Lubanie, z bogato wyposażonymi pochówkami o licznych śladach wpływów kulturowych z różnych części Europy, w tym Skandynawii ${ }^{35}$.

Znaleziska przedmiotów o skandynawskiej proweniencji zarejestrowane na terenie Wielkopolski wiązać należy z drugą fazą napływu „importów” na ziemie polskie, datowaną na drugą poł. X i XI w. ${ }^{36}$. Zdaniem J. Żaka to czasy najznaczniejszego ich napływu, odbywającego się głównie za sprawą kupców pochodzących z Birki, Sigtuny i Haithabu, a częściowo również z Gotlandii, Lund i Zelandii. Współzawodniczyli z nimi handlarze słowiańscy, m.in. z Wolina, Kołobrzegu i Gdańska ${ }^{37}$. Równolegle z wymianą handlową następowała imigracja, dobrowolna lub przymusowa, elit służących w drużynie książęcej lub w związku z małżeństwami, również dynastyczny$\mathrm{mi}^{38}$. Nie ulega wątpliwości, że Skandynawowie bądź Słowianie przebywający przez dłuższy czas na północnych wybrzeżach Bałtyku stanowili znaczący odsetek drużynników książęcych ${ }^{39}$. Wskazują na to liczne pochówki zbrojnych wyróżniające się bogatym wyposażeniem, względnie konstrukcją grobów ${ }^{40}$.

33 M. Kara, Ze studiów nad elitarną kulturą ludności grodów tzw. centralnych państwa pierwszych Piastów, czyli ponownie o wczesnośredniowiecznym grzebieniu ze Stroszek pod Gieczem. Ujęcie porównawcze, Slavia Antiqua, 60 (2019), s. 107-191.

34 J. Żak, „Importy” skandynawskie, s. 301-302.

35 Bodzia. Elitarny cmentarz z początków państwa polskiego, red. A. Buko, Warszawa 2016.

36 J. Żak, Problem „importów" skandynawskich, s. 185-186.

37 Tamże, s. 185.

38 K. Jasiński, Genealogia pierwszych Piastów, Poznań 2004, s. 94 n.

39 M. Kara, Z badań nad, s. 35 nn; M. Kara, Sity zbrojne, s. 112-113; A. Buko, Archeologia Polski wczesnośredniowiecznej, Warszawa, 2011, s. 302.

40 Z tym ostatnim zagadnieniem wiąże się chętnie przywoływana w nowszej literaturze problematyka grobów tzw. komorowych, niekiedy wprost uznawanych za recepcję wzorców skandynawskich, lub też wiązanych raczej z elitami, również wywodzącymi się z lokalnych społeczno- 
Zachodnioeuropejskie oddziaływania na kulturę elitarną państwa pierwszych Piastów mają odmienny charakter. Są one uchwytne w socjotopografii centrów polityczno-administracyjnych oraz recepcji form architektury monumentalnej - świeckiej i sakralnej ${ }^{41}$. Charakterystykę takich ośrodków przedstawiła Zofia Kurnatowska, pisząc: „W obrębie tych grodów i na ich zapleczu skupione były owe najważniejsze siły państwa, tam ściągano i chroniono bogactwa z łupów, danin i trybutów. Zarazem grody stanowily punkty obrony centrum państwa, a ponadto $\mathrm{m}$. in. poprzez kontrast w stosunku do wcześniejszych niewielkich gródków - manifestację potęgi nowej władzy (...). Grody te są często wieloczłonowe, z czym wiąże się zróżnicowanie funkcji poszczególnych członów grodu. Jednocześnie ma miejsce organizacja zaplecza osadniczego, osadzanie ludności usługowej a także trudniącej się różnymi działami wytwórczości” ${ }^{42}$. Należy dodać, że grody centralne, takie jak Giecz ${ }^{43}$, Gniezno ${ }^{44}$, Ostrów Lednicki ${ }^{45}$ i Poznań ${ }^{46}$ - poprzez inwestycje w nich podejmowane przez członków rodu panującego, pełniły istotne funkcje kulturotwórcze, przejawiające się adaptacją wzorców artystycznych z terenów ościennych. Do najlepiej rozpoznanych

ści, por. A. Janowski, Groby komorowe w Europie Środkowo-Wschodniej. Problemy wybrane, Szczecin 2015; Pochówki w grobach komorowych na ziemiach polskich w okresie wczesnego średniowiecza, red. D. Błaszczyk, D. Stępniewska, Warszawa 2016; H. Kóčka-Krenz, Formowanie się elit państwa wczesnopiastowskiego w źródłach funeralnych, Quaestiones Medii Aevi Novae (2019), s. 323-339.

${ }^{41}$ T. Rodzińska-Chorąży, Zespoty rezydencjonalne i kościoły centralne na ziemiach polskich do połowy XII wieku, Kraków 2009; L. Wetesko, Historyczne konteksty monarszych fundacji artystycznych $w$ Wielkopolsce do początku XIII wieku, Poznań 2009.

42 Z. Kurnatowska, Rola grodów wczesnopiastowskich $w$ organizacji osadnictwa i państwa polskiego, [w:] Historia prawa - Historia kultury. Liber Memorialis Vitoldo Maisel dedicatus, red. E. Borkowska-Bagieńska, H. Olszewski, Poznań 1994, s. 63-74; Z. Kurnatowska, Wczesnopiastowskie grody centralne. Podobieństwa i różnice, [w:] Gniezno i Poznań w państwie pierwszych Piastów, red. A. Wójtowicz, Poznań 2000, s. 9-31, por. s. 11, 12.

43 T. Krysztofiak, Palatium w Gieczu - archeologiczne podstawy datowania reliktów, [w:] Lapides viventes. Zaginiony Kraków wieków średnich. Księga dedykowana Profesor Klementynie Żurowskiej, red. J. Gadomski, A. Małkiewicz, T. Rodzińska-Chorąży, A. Włodarek, Kraków 2005, s. 293-309.

44 Gniezno. Wczesnośredniowieczny zespół grodowy, red. T. Sawicki, M. Bis, Warszawa 2018.

45 Ostrów Lednicki. Rezydencjonalno-stołeczny ośrodek pierwszych Piastów, red. Z. Kurnatowska, A.M. Wyrwa, Warszawa 2016.

46 H. Kóčka-Krenz, Stan badań nad wczesnośredniowiecznymi palatiami, [w:] Stan i potrzeby badań nad wczesnym średniowieczem w Polsce - 15 lat później, red. W. Chudziak, S. Moździoch, Toruń-Wrocław-Warszawa 2006, s. 51-61. 
pod tym względem należy gród założony na Ostrowie Tumskim w Poznaniu, w którym szczególnie uwidoczniły się wpływy kulturowe z terenów cesarstwa Ottonów.

Znaczenie Poznania pod tym względem zaznaczyło się wyraziście od początku panowania Mieszka I, który w sposobie organizacji przestrzeni grodu naśladował główne siedziby władców niemieckich z czasów karolińsko-ottońskich ${ }^{47}$. Wznoszono $\mathrm{w}$ nich kamienne palatia $\mathrm{z}$ wydzielonymi przedsionkami prowadzącymi do komnat wyposażonych w kominki, a także z piwnicami na wina i loggiami. Do części świeckich rezydencji przylegały kamienne kaplice, zaś na terenie dziedzińca lokowane były drewniane domy mieszkalne (także dla gości), warsztaty, pomieszczenia do pracy dla kobiet z komnatą, kuchnie, piekarnie, stajnie, stodoły i spichlerze zbożowe, oraz - gdy dostępna przestrzeń na to pozwalała - sad, staw rybny i ogród. Musiały być wyposażone we wszystkie niezbędne w codziennym życiu przedmioty, „żeby nie trzeba było o nie prosić, gdy będą potrzebne"48. Takimi cechami, w formie przystosowanej do ówczesnych możliwości i potrzeb, odznaczał się gród w Poznaniu. Obserwowane przez pryzmat źródeł archeologicznych materialne przejawy funkcji pełnionych w jego obrębie dają wyraźne podstawy do sądu, że był on ważnym miejscem sprawowania władzy we wczesnopiastowskim organizmie politycznym, jako jeden z kilku grodów w środkowej części Wielkopolski, będących „specyficznym rodzajem 'miejsca centralnego' (...), które spełniały cały kompleks funkcji charakterystycznych dla danego okresu. Były to najczęściej funkcje centralne, które (...) można określić hasłowo jako funkcje: ośrodka produkcji, wymiany, kultu, władzy, obrony, informacji”"49. Istotną cechą piastowskich władców było podejmowanie szeroko zakrojonych kontaktów kulturowych, uchwytnych zarówno poprzez recepcję monumentalnej architektury - zwłaszcza w ich poznańskiej rezydencji, jak i poprzez - na pozór drobne - znaleziska, świadczące o powiązaniach z elitarnymi ośrodkami zachodniej Europy.

Cechą wyróżniającą poznański gród spośród pozostałych grodów centralnych, wzniesionych lub rozbudowanych w czasach panowania Mieszka I, był jego układ

47 H. Kóčka-Krenz, Na wyspie Ostrów, przy której dzisiaj jest Poznań..., Poznań 2012; taż, Palatium poznańskie na tle wczesnośredniowiecznych zespotów rezydencjonalnych, [w:] Archeologiczne tajemnice palatium i katedry poznańskiego Ostrowa, red. M. Przybył, Poznań 2016, s. 21-46.

48 W. Metz, Die Königshöfe der Brevium Exempla, Deutsches Archiv für Erforschung des Mittelalters 22 (1966), s. 598-617, rozdz. 32.

49 S. Moździoch, Miejsca centralne Polski wczesnopiastowskiej. Organizacja przestrzeni we wczesnym średniowieczu jako źródło poznania systemu społeczno-gospodarczego, [w:] Centrum i zaplecze we wczesnośredniowiecznej Europie Środkowej, red. S. Moździoch, Wrocław 1999 , s. $20-51$, por. s. $23-24$. 
przestrzenny. Było to jedyne wówczas tak specyficznie ukształtowane miejsce warowne, składające się z czterech osobnych, wydzielonych wałami części. Taki podział zajętego przez gród terenu wynikał zapewne z niejednolitej powierzchni wyspy uformowanej z rzecznych piasków w rozlewiskach Warty. Zaznaczające się na niej wyniesienia, włączane kolejno w obręb rozbudowywanej fortalicji ${ }^{50}$, w naturalny sposób wyznaczały jej czteroczłonowy układ. Można jednak wysunąć tezę, że idea wydzielania osobnych przestrzeni w obrębie jednego grodu została zaczerpnięta ze sposobu organizacji siedzib cesarskich środkowej Europy. Podział na wyodrębnioną w terenie część rezydencjonalną i gospodarczą był w nich stosowany co najmniej od przełomu VIII i IX w., o czym świadczy struktura grodu „Höfe” koło Dreihausen, Kr. Marburg-Biedenkopf w Hesji i kontynuowany w X w., czego przykładem jest wydzielona część pałacowa w grodzie Werla koło Wolfenbüttel w Dolnej Saksonii ${ }^{51}$. Gród ten był ważnym miejscem za panowania Ottonów, na co wskazują wzmianki o czternastokrotnym w nim pobycie władców z tej dynastii między 924 a 1013 r. $^{52}$ Nie można więc całkowicie wykluczyć przypuszczenia, że Mieszko I znał tę ottońską rezydencję ${ }^{53}$ - jeżeli nie osobiście, to z relacji - i wprowadził zasadę otaczania osobnym wałem zespołów pałacowo-sakralnych w swych głównych wielkopolskich siedzibach, od poznańskiego grodu poczynając ${ }^{54}$.

Wyrazistym śladem kontaktów kulturowych państwa Piastów z cesarstwem Ottonów jest recepcja form architektury monumentalnej. Rezydencje wczesnopiastowskie, podobnie jak siedziby władców z czasów karolińsko-ottońskich w środ-

50 H. Kóčka-Krenz, Poznań w czasach panowania pierwszych Piastów, [w: ] Ziemia, człowiek, sztuka, red. U. Mazurczak, Lublin 2015, s. 71-98.

51 G. Streich, Burg und Kirche während des deutschen Mittelalters. Untersuchungen zur Sakraltopographie von Pfalzen, Burgen und Herrensitzen, T. I. Pfalz-und Burgkapellen bis zur staufischen Zeit, Sigmaringen 1984, s. 87, ryc. 27, s. 153-156, ryc. 47; G. Binding, Deutsche Königspfalzen. Von Karl dem Großen bis Friedrich II (765-1240), Darmstadt 1996, s. 70.

52 H. Beumann, Die Ottonen, Stuttgart 1987; H.K. Schulze, Hegemoniales Kaisertum - Ottonen und Salier, Das Reich und die Deutschen, t. 3, Berlin 1991; E. Eickhoff, Theophanu und der König: Otto III. und seine Welt, Stuttgart 1996; G. Althoff, Die Ottonen. Königsherrschaft ohne Staat, Stuttgart 2000.

53 Przypuszczenie to wzmacnia podobieństwo kaplicy pałacowej w Werli do kaplicy przy palatium na Ostrowie Lednickim. Wobec braku możliwości precyzyjnego wskazania czasu budowy obydwu obiektów pozostaje rzeczą dyskusyjną kwestia, czy Werla stanowiła wzorzec dla Ostrowa Lednickiego, czy też odwrotnie; por. G. Streich, Burg und Kirche, s 156.

54 H. Kóčka-Krenz, Palatia wczesnopiastowskie, [w: Ś́redniowiecze w rozjaśnieniu, red. K. Skupieński, Warszawa 2010, s. 119-132. 
kowej Europie, składały się zazwyczaj z różnorako powiązanych ze sobą członów - pomieszczeń mieszkalnych, budowli salowej o funkcjach reprezentacyjnych i połączonej z nią kaplicy ${ }^{55}$. Takie rozwiązanie - $\mathrm{w}$ formie zredukowanej do palatium i kaplicy - zastosowano w rezydencji zbudowanej w książęcej partii grodu poznańskiego. Świecka jej część była prostokątnym budynkiem o wymiarach 27 x 12 m, założonym na osi północ-południe ${ }^{56}$. Ściany obwodowe budynku zostały wzniesione z kamieni łamanych w płytki, spajanych grubą warstwą gipsowych zapraw. Pokrywał je gipsowy tynk, zarówno od wewnętrznej, jak i zewnętrznej strony. Posadzki $\mathrm{w}$ pomieszczeniach palatium były także wykonane $\mathrm{z}$ wylewki gipsowej położonej na warstwie okruchów skalnych. Przy południowo-wschodnim narożniku palatium wprowadzono przelotową sień, szeroką na 2,20 m. Mieściła się w niej także klatka schodowa prowadząca na piętro. Dwukondygnacyjne poznańskie palatium książęce mogło osiągać wysokość około $11 \mathrm{~m}$. Na parterze budynku wyodrębniono co najmniej cztery pomieszczenia. Sień w jego południowej części (niemal $5 \mathrm{~m}^{2}$ ) sąsiadowała od północy z pokojem $\left(51 \mathrm{~m}^{2}\right)$, który poprzedzał środkową, dużą salę $\left(102 \mathrm{~m}^{2}\right)$ o funkcjach reprezentacyjnych. Do sali tej prowadziło osobne wejście, umieszczone w ścianie wschodniej palatium. Z jej wnętrza, przez przejścia w północnej ścianie działowej były dostępne dwa pozostałe pomieszczenia. Jedno to wąski korytarz o szerokości zaledwie $90 \mathrm{~cm}$, lecz długości $5 \mathrm{~m}\left(4,5 \mathrm{~m}^{2}\right)$, być może skarbczyk. Przylegająca do niego od wschodu ostatnia sala zajmowała przestrzeń $34 \mathrm{~m}^{2}$. Odkryte w jej obrębie dwa tłoki pieczętne: mocno zużyty ołowiany - o niemożliwym już do odczytania wyobrażeniu - i brązowy, należący do brata Jakuba z zakonu dominikanów ${ }^{57}$, ponadto ołowiana bulla księcia Bolesława ${ }^{58}$ wskazują, że sala ta mieściła kancelarię. W oparciu o dane metryczne można oszacować powierzchnię użytkową każdej kondygnacji na około $190 \mathrm{~m}^{2}$. Pomieszczenia na parterze pełniły funkcje administracyjno-reprezentacyjne, zaś na piętrze mieściły się zapewne prywatne pokoje władcy. Przy wschodniej ścianie palatium - w jej południowym odcinku, na osi

\footnotetext{
55 G. Binding, Deutsche Königspfalzen, s. 64, 168-178.

56 H. Kóčka-Krenz, Na wyspie Ostrów, s. 20-30.
}

57 A. Dębski, I. Marciniak, Średniowieczny tłok pieczętny odkryty na stanowisku Poznań-Ostrów Tumski 9/10, [w:] Poznań we wczesnym średniowieczu, red. H. Kóčka-Krenz, t. 5, Poznań 2005, s. 161-168.

58 I. Dębska, A. Dębski, M. Sikora, Wczesnośredniowieczna pieczęć ołowiana odkryta na poznańskim Ostrowie Tumskim, [w:] Poznań we wczesnym średniowieczu, red. H. Kóčka-Krenz, t. 6, Poznań 2008, s. 99-110. 
przelotu bramnego - zbudowano orientowaną kaplicę grodową ${ }^{59}$. Kaplica ta jest niewielkim kościołem salowym, zamkniętym od wschodu absydą o wymiarach 2,5 x $2,5 \mathrm{~m}$. Wnętrze nawy poszerzono, wykonując w grubości ścian dwa aneksy, przez co jej powierzchnia zajmowała $10 \mathrm{~m}^{2}$. W ścianach aneksów zamontowano zaopatrzone w parapety okna, o szerokości około $0,75 \mathrm{~m}$ i wysokości $1,30 \mathrm{~m}$, umieszczone na wysokości około $0,55 \mathrm{~m}$ od posadzki. Tak nisko posadowione okna każą przypuszczać, że kaplicę oświetlał jeszcze górny rząd okienek, zapewne też okno w absydzie. Posadzkę tworzyła wylewka gipsowa położona na warstwie drobnych, naturalnych kamieni, która przetrwała w dużych połaciach w absydzie. Do jej ściany dostawiony był stół ofiarny, którego prostokątną podstawę wymurowano z drobniejszych kamieni płytowych łączonych zaprawą gipsową i ozdobiono (niestety niezachowaną) okładziną. Kaplica była otynkowana, jej ściany pokrywały malowidła, zaś absydę - mozaika ze szklanych kostek. Świątynię wyposażono w relikwiarz skrzynkowy, zapewne także w inne przedmioty niezbędne do sprawowania liturgii.

Kamienna rezydencja wznosząca się w poznańskim grodzie była pierwszą monumentalną budowlą w państwie Piastów. Można sądzić, że Mieszko I sprowadził w tym celu specjalistów z terenu cesarstwa Ottonów, od których jego podwładni mogli nauczyć się konstruowania nowego typu założeń, łączących funkcje mieszkalno-reprezentacyjne z liturgicznymi. Jednak nie można wskazać obiektu, który byłby bezpośrednim wzorcem dla rozwiązania zastosowanego w Poznaniu. Wynika to po części z faktu, że także cesarskie rezydencje z tego czasu były wielokrotnie przebudowywane. Ich pierwotne bryły są rekonstruowane w oparciu o relikty rozpoznawane zazwyczaj podczas badań architektoniczno-archeologicznych ${ }^{60}$. Na ich podstawie można jednak stwierdzić, że architekturę karolińsko-ottońską cechuje odmienność rozwiązań formalnych stosowanych w każdej z cesarskich siedzib i fundacji sakralnych. Najbardziej zbliżony układ zastosowano w bawarskim opactwie benedyktynek na Fraueninsel, Chiemsee (IX w. $)^{61}$, którego dwupoziomową kaplicę z prostokątnym prezbiterium wzniesiono po wschodniej stronie przelotowej bramy, prowadzącej do wnętrza opactwa. W opactwie benedyktynek od zachodu do przejścia bramnego

59 H. Kóčka-Krenz, Najstarsze kościoły poznańskiego grodu, [w: ] Kościoły w dobie chrystianizacji, red. M. Rębkowski, Szczecin 2016, s. 117-135.

60 Por. Vorromanische Kirchenbauten. Katalog der Denkmäler bis zum Ausgang der Ottonen, opr. F. Oswald, L. Schaefer, H.R. Sennhauser, München1966; Vorromanische Kirchenbauten. Katalog der Denkmäler bis zum Ausgang der Ottonen. Nachtragsband, opr. W. Jacobsen, L. Schaefer, H.R. Sennhauser oraz M. Exner, J. Mertens, H. Stvepker, München1991.

61 H. Dannheimer, Thorhalle auf Frauenchiemsee, Regensburg 1995, s. 15-21. 
przylega południowe skrzydło klasztoru, w rezydencji poznańskiej - południowa partia pałacu książęcego. Byłaby to pośrednia wskazówka, że strzecha budowlana zatrudniona przy budowie zespołu pałacowo-sakralnego w Poznaniu pochodziła z Bawarii. Być może jednak władca nie musiał sięgać po budowniczych aż tak daleko, gdyż podobnymi rozwiązaniami technicznymi cechują się obiekty sakralne wznoszone we wschodniej części Cesarstwa Ottonów. Wśród nich na uwagę pod tym względem zasługuje fundacja grafa Lotara $\mathrm{II}^{62}$, który założył klasztor rodowy w swym grodzie w Walbeck (Börde, Sachsen-Anhalt) ${ }^{63}$. Co istotne, zbudowany około 942 r. kościół klasztorny pod wezwaniem św. Marii, Pankracego i Anny był pierwotnie budowlą salową z transeptem i absydą, której mury zostały wyciągnięte w technice opus emplectum z surowców skalnych łamanych w różnej grubości płyty, w tej samej technice, w jakiej zbudowano poznańską rezydencję. Ważną wskazówką co do pochodzenia strzechy budowlanej sprowadzonej do Poznania jest lokalizacja obiektów architektury, w których - podobnie jak to miało miejsce we wczesnopiastowskim budownictwie monumentalnym głównych ośrodków wielkopolskich jako surowca do sporządzania zapraw murarskich używano gipsu. Stosowanie takich spoiw wymagało dostępności do jego złóż i odpowiedniej wiedzy technicznej, która musiała być przekazywana w sposób bezpośredni podczas prac budowlanych. $\mathrm{W}$ architekturze wczesnopiastowskiej wykorzystywano miejscowe wychodnie gipsu, których złoża eksploatowano w pobliżu dzisiejszego Wapna na Pałukach ${ }^{64}$, ale znajomość ich przetwarzania w celu spajania elementów budowlanych musiała być zaczerpnięta z zewnątrz. Taką znajomością legitymizowali się budowniczowie, którzy $\mathrm{w}$ połowie $\mathrm{X}$ w. wznieśli kamienny budynek świecki połączony z kościołem w formie krzyża łacińskiego w Werli koło Goslaru w Dolnej Saksonii ${ }^{65}$. Podłogi w obydwu tych budynkach, jak również w tzw. pałacu I usytuowanym przy południowym skraju głównej części grodu (tzw. Kernburg) zostały wykonane z zaprawy gipsowej, co

62 Graf Lotar II był dziadkiem biskupa merseburskiego Thietmara, którego kronika jest najważniejszym źródłem do dziejów państwa pierwszych Piastów.

63 J. Cramer, S. Breitling, Die Stiftskirche in Walbeck, [w: Die Ottonen. Kunst - Architektur - Geschichte, red. K.G. Beuckers, J. Cramer, M. Imhof, Petersberg 2002 (wyd. 2), s. 273-278.

64 J. Skoczylas, Gipsowe zaprawy murarskie w początkach państwa polskiego, Slavia Antiqua 55 (2014), s. 171-178.

65 G. Binding, Deutsche Königspfalzen. Von Karl dem Großen bis Friedrich II. (765-1240), Darmstadt 1996, s. 168-178; K. Żurowska, Zespót pałacowy w Werli. Ze studiów nad wczesnośredniowiecznq architektura patacowa, [w:] Magistro et amico amici discipulique. Lechowi Kalinowskiemu w osiemdziesięciolecie urodzin, red. W. Bulsza, L. Sadko, Kraków 2002, s. 147-164; por. s. 150. 
w tym czasie stanowiło wyróżnik budowli elitarnych ${ }^{66}$. Biorąc powyższe pod uwagę można postawić domysł, że do wznoszenia wielkopolskich zespołów pałacowo-sakralnych zaangażowano budowniczych, którzy działali na terenie Dolnej Saksonii.

Z kwestią powyższą łączy się próba odpowiedzi na pytanie o recepcję form architektury sakralnej wzniesionej w obrębie poznańskiego grodu ${ }^{67}$. Wnętrze tutejszej kaplicy pałacowej ma formę zbliżoną do krzyża łacińskiego. Jako przykład tego typu rozwiązań można przytoczyć datowany na drugą poł. VIII w. kościół w Molzbichl (Karyntia) ${ }^{68}$, pochodzący z przełomu VIII i IX w. kościół w Uznach koło St. Gallen ${ }^{69}$, a zwłaszcza zaopatrzony w dwa aneksy w absydzie kościół w Eldagsen koło Hildesheim, zbudowany przed $1000 \mathrm{r} \cdot{ }^{70} \mathrm{Z}$ uwagi na - oprócz liturgicznego - także zapewne sepulkralne przeznaczenie ${ }^{71}$ należy przywołać jeszcze jeden obiekt - kaplicę wzniesioną około 800 r. po zachodniej stronie katedry w Halberstadt ${ }^{72}$. Zarys tej kaplicy stanowi niemal lustrzane odbicie poznańskiej kaplicy pałacowej, choć jej wnętrze w partii zachodniej rekonstruuje się jako uformowane w trikonchos ${ }^{73}$.

Pod koniec życia Mieszka I ${ }^{74}$ - na co wskazują źródła archeologiczne ${ }^{75}$ - rozpoczęto budowę najstarszej w jego państwie katedry pod wezwaniem św. Piotra, ulo-

66 M. Geschwinde, In presidio urbis. Die Befestigungen der Königspfalz (= Werla 3 = Römisch-Germanisches Zentralmuseum zu Mainz), Mainz 2017. Aula pałacowa była ogrzewana gorącym powietrzem (hypocaustum), co jest ewenementem w architekturze tego czasu.

67 Budynki świeckie w rezydencjach tego czasu są w generalnych zarysach podobne, zakładane zazwyczaj na planie prostokąta; różni je sposób rozwiązania partii wejściowej i podziału wnętrza.

68 Vorromanische Kirchenbauten (1991), s. 287.

69 Vorromanische Kirchenbauten (1966), s. 358-359.

70 Tamże, s. 404.

71 Wskazuje na to głęboki wkop w jej wnętrzu, stanowiący zapewne ślad po translacji szczątków pochowanej w tym miejscu osoby; por. H. Kóčka-Krenz, Najstarsze kościoły, s 126.

72 W środku nawy tej kaplicy został wybudowany grobowiec; G. Leopold, E. Schubert, Der Dom zu Halberstadt bis zum gotischen Neubau, Berlin 1984, s. 36-38.

73 Zamieszczona w wyżej cytowanej pracy dokumentacja rysunkowa nie przesądza takiej rekonstrukcji; równie dobrze boczne ramiona tej kaplicy mogły być zamknięte prosto także w jej wnętrzu.

74 Z. Kurnatowska, Początki Polski, Poznań 2002, s. 109.

75 Z. Kurnatowska, M. Kara, Początki architektury sakralnej na grodzie poznańskim w świetle nowych ustaleń, [w: ] Początki architektury monumentalnej $w$ Polsce, red. T. Janiak, D. Stryniak, Gniezno 2004, s. 47-70; natomiast S. Skibiński, Katedra poznańska, Poznań 2001, s. 20-21, przesuwa początek budowy katedry na czas po 1000 r.; na temat podstaw datowania ostatnio A. Bukowska, Najstarsza katedra $w$ Poznaniu. Problem formy i jej genezy $w$ kontekście architektury około roku 1000, Kraków 2013, s. 160-164, 255. 
kowanej na poznańskim grodzie w bezpośrednim sąsiedztwie rezydencji. Relikty jej najstarszych faz były przedmiotem intensywnych badań, prowadzonych od 1951 do $1956 \mathrm{r}^{76}$ Zbudowano ją na fundamentach z dużych naturalnych głazów granitowych wiązanych zaprawą wapienną, na których wyciągnięto ściany z płytek kamiennych pokryte wapiennym tynkiem, zaś posadzkę uformowano z twardej, gładkiej płyty wapiennej. Była to trójnawowa bazylika długości $49 \mathrm{~m}$, z nawą główną szerokości $8,4 \mathrm{~m}$, zaś nawami bocznymi - 4,2 $\mathrm{m}$. Nawa główna była prawdopodobnie wydzielona arkadami wspartymi na filarach, a wszystkie trzy nawy nakrywał płaski strop. Otwory okienne i portale znajdujące się w północnej i południowej ścianie miały zapewne starannie opracowane ościeża. W centrum jej nawy głównej zainstalowano wydzielone murkiem mauzoleum, zawierające dwa pochówki, identyfikowane z miejscem spoczynku Mieszka I i Bolesława Chrobrego ${ }^{77}$. Zaproponowany przez Krystynę Józefowiczównę zarys katedry tej fazy został ostatnio zweryfikowany przez Anetę Bukowską, która w efekcie gruntownej analizy reliktów odkrytych podczas badań zaproponowała odmienną rekonstrukcję partii wschodniej i zachodniej tej budowli ${ }^{78}$. Według niej kwadratowemu prezbiterium zakończonemu apsydą towarzyszyły dwa prostokątne pomieszczenia, wysunięte o grubość muru obwodowego poza linię przebiegu murów trójprzęsłowego korpusu nawowego. Układ partii wschodniej został powtórzony w części zachodniej kościoła, ze zwieńczonym wieżą kwadratowym przęsłem na przedłużeniu nawy głównej i flankującymi je dwoma pomieszczeniami. Masyw zachodni zawieral piętro emporowe, wsparte na podporze w osi kościoła. W efekcie najstarsza bazylika była kościołem dwutranseptowym, z prostym zamknięciem od zachodu i wejściem od południa, umieszczonym w środkowym przęśle korpusu nawowego ${ }^{79}$. Istotną różnicą w stosunku do dotychczasowych ujęć w organizacji przestrzeni chóru wschodniego katedry jest konstatacja A. Bukowskiej, że prezbiterium było dwupoziomowe, z kryptą halową wspartą na czterech filarach, do której dostęp prowadził przez boczne pomieszczenia ${ }^{80}$. Pierwszy kościół katedralny na grodzie poznańskim był monumentalną bazyliką, której program budowlany i zawarte $\mathrm{w}$ nim treści symboliczne wskazują na związki z nie-

$76 \mathrm{~K}$. Józefowiczówna, $Z$ badań nad architektura przedromańska i romańska $w$ Poznaniu, Wrocław-Warszawa-Kraków 1963, s. 7-9.

77 H. Kóčka-Krenz, Pochówki królewskie w katedrze poznańskiej, Ecclesia. Studia z dziejów Wielkopolski 2 (2006), s. 39-55.

78 A. Bukowska, Najstarsza katedra, s. 165-171.

79 Tamże, s. 166, ryc. 149.

80 Tamże, s. 210, ryc. 189. 
miecką architekturą monumentalną, zaś bezpośrednim dla niego wzorcem był zapewne kościół klasztorny w Memleben, Sachsen-Anhalt. Zdaniem A. Bukowskiej, która przeprowadziła wnikliwą analizę rozplanowania bazyliki poznańskiej na tle porównawczym „katedra w Poznaniu przedstawia się jako jedyna dotychczas rozpoznana wśród najstarszych budowli wczesnopiastowskich budowla o ottońskim programie architektonicznym bezpośrednio inspirowanym pierwowzorem cesarskim. (...) jej forma, inspirowana artystyczną myślą twórców związanych ze środowiskiem cesarskim, miała te cechy, które pozwalają stwierdzić, że projekt ukończono wedle ówczesnych nowinek architektonicznych realizowanych dla domu cesarskiego" ${ }^{\text {. }}$. Nie znamy wystroju i wyposażenia pierwszej poznańskiej katedry, lecz można odnieść do tej kwestii opinię P. Skubiszewskiego: „Zachowanych fragmentów architektury pierwszych katedr i dzieł, które mogły do nich należeć, jest zatem bardzo mało (...). Jest to stan zachowania bez wątpienia gorszy od tego, co przetrwało z architektury, urządzenia, sprzętu i ksiąg innych katedr europejskich w tym samym czasie od nowa wznoszonych albo przebudowywanych i wyposażanych. Pozostało więc niewiele, lecz to, co znamy, pozwala sądzić, że swym zasadniczym kształtem i wyposażeniem nasze pierwsze katedry nie odbiegały wcale albo nieznacznie od tego, co mieli ówcześnie do dyspozycji w swych siedzibach inni biskupi europejscy. (...) Próbując wyobrazić sobie dzisiaj wnętrze i sprzęty katedry polskiej tamtych lat, mamy zatem prawo odnieść do niej to, co na podstawie źródeł pisanych i zachowanych dzieł wiemy o katedrach karolińskich i przedromańskich" ${ }^{82}$.

Konstatację P. Skubiszewskiego wspierają zachowane fragmenty wyposażenia kaplicy pałacowej poznańskiego grodu. Jej ściany zostały starannie wygładzone gipsowymi tynkami, na które naniesiono dekoracje malarskie, z użyciem typowych dla malarstwa ściennego pigmentów - bieli wapiennej, czerwieni żelazowej i błękitu. W wyniku specjalistycznych analiz ${ }^{83}$ ustalono, że były to warstwowo nakładane kremowo-białe tynki wapienne z domieszką włókien roślinnych. Mokry tynk został pomalowany farbą o spoiwie organicznym zawierającym białko, ewentualnie z dodatkiem kleju roślinnego. Biel i czerwień uzyskano z surowców dostępnych na miejscu, natomiast błękit wydobywano z lazurytu, którego najbardziej znane złoża

\footnotetext{
81 Tamże, s. 256.

82 P. Skubiszewski, Katedra $w$ Polsce około roku 1000, [w: ] Polska na przełomie I i II tysiąclecia, red. S. Skibiński, Poznań 2001, s. 139-196; por. s. 151.

83 Analizy wykonała Anna Michnikowska z Muzeum Narodowego w Poznaniu i Jerzy Langer z Wydziału Chemii UAM.
} 
znajdują się w Badachszanie (Afganistan) ${ }^{84}$. Niestety fragmenty tynku są zbyt małe, by dać podstawy do odtworzenia tematyki dekoracji malarskiej. Mogły to być zarówno motywy geometryczne, jak i ujęte w ramy przedstawienia figuralne, gdyż widoczne na kilku fragmentach białe i czerwone pasma zapewne wyznaczały pola dekoracji. Pokrywanie ścian przedromańskich świątyń scenami o tematyce zaczerpniętej ze Starego i Nowego Testamentu, umieszczanymi w polach ograniczonych geometrycznymi lub roślinnymi bordiurami, było zabiegiem często stosowanym, czego dobrym przykładem są malatury w kościele św. Jerzego na wyspie Reichenau-Oberzell w Badenii-Wirtembergii ${ }^{85}$.

W chrześcijańskiej świątyni nie mogło zabraknąć przedmiotów niezbędnych podczas sprawowania liturgii. Podczas badań wykopaliskowych na Ostrowie Tumskim pozyskano jedynie fragmenty kościanych okładzin, które pierwotnie zdobiły dwa, różnie wykonane schowki na relikwie. Z relikwiarza skrzynkowego, który stanowił wyposażenie kaplicy pałacowej, zachowało się kilkanaście fragmentów kościanych listewe ${ }^{86}$. Przykłady komponowania zewnętrznego wystroju skrzynek z takich listewek obrazują zachowane w całości relikwiarze z Nadrenii. Najbliższy poznańskiemu w typie dekoracji jest relikwiarz z kościoła św. Andrzeja w Kolonii wykonany z drewna dębowego, datowany na koniec XI-XII w. ${ }^{87}$ Zbliżoną formą cechuje się stosunkowo duża skrzynka na relikwie z kościoła św. Gereona w Kolonii, sporządzona z drewna orzechowego i ozdobiona ażurowanymi kościanymi płytkami nałożonymi na złocony podkład. Spajające skrzyneczkę żelazne okucia o rozwidlonych końcach wskazują na jej wykonanie na przełomie XI i XII w. ${ }^{88}$ Fragmenty płytek kościanych zarejestrowano także w południowej części Ostrowa Tumskiego w Poznaniu - na tzw. Zagórzu. One także są pozostałością relikwiarza, który został zapewne ozdobiony kilkoma prostokątnymi płytkami o powtarzalnym module, otoczonymi bordiurą z listewek zdobionych plecionką. Ich ażurowany motyw stanowił okrąg z wyciętym środkiem, od którego rozchodziło się promieniście pięć ramion

\footnotetext{
84 K. Maślankiewicz, Kamienie szlachetne, Warszawa 1983, s. 223-224.

85 P. Skubiszewski, Malarstwo karolińskie i przedromańskie, Warszawa 1973, s. 221-223; D. Jakobs, Sankt Georg in Reichenau-Oberzell. Der Bau und seine Ausstattung, cz. 1, Stuttgart 2000.

86 H. Kóčka-Krenz, Relikwiarze z Ostrowa Tumskiego w Poznaniu, [w:] Res et Fontes, red. T. Galiński i E. Wilgocki, Szczecin 2003, s. 211-221.

87 Das Reich der Salier 1024 - 1125. Katalog zur Ausstellung des Landes Rheinland-Pfalz, Sigmaringen 1992, s. 351-353.

88 Tamże, s. 348, 353.
} 
połączonych z zewnętrznym okręgiem, dekorowanym podwójną linią punktowanych kółek. Był to zapewne pojemnik zbliżony swą formą do zachowanego w całości relikwiarza skrzynkowego z kościoła św. Kosmy i Damiana w Wunstorf w Dolnej Saksonii. Relikwiarz ten jest stosunkowo dobrze datowany - na jego pokrywie, w dwóch kolistych wycięciach zostały umieszczone monety Ottona I (936-937) lub Ottona III (983-1002), co pozwala określić czas jego wykonania na drugą połowę X-początek XI w. ${ }^{89}$ Odpowiednikiem poznańskiej skrzyneczki z Ostrowa Tumskiego-Zagórza mógł być także relikwiarz domkowy z Oldenburga Wagryjskiego. Okładziny kościane tego relikwiarza zostały odsłonięte $w$ warstwie datowanej na połowę $\mathrm{XI}$-połowę XII w., co pozwala uznać go za wytwór z pierwszej połowy XI w..$^{90}$ Takie schowki na relikwie, ze względu na niewielkie rozmiary i charakter dekoracji, mieszczą się w nurcie wczesnośredniowiecznego rzemiosła artystycznego, zaś zachowane ich przykłady wskazują, że mogły zostać sporządzone w drugiej połowie X-XI w. w jednym z zachodnioeuropejskich ośrodków rzemiosła artystycznego ${ }^{91}$.

Z przedmiotami związanymi z liturgią można też zapewne łączyć znaleziska gemm - jednej szklanej (dziś niestety zaginionej) i drugiej karneolowej z wyobrażeniem lwa (późnorzymskiej, antycznej) ${ }^{92}$, których we wczesnym średniowieczu używano do wykładania relikwiarzy, krzyży, kielichów, czy okładzin ksiąg liturgicznych $^{93}$. Te drobne elementy wystroju są przekonującym świadectwem, że świątynie poznańskiej rezydencji książęcej były zaopatrywane w przedmioty kultu chrześcijańskiego pochodzące z wyspecjalizowanych warsztatów złotniczych zachodniej Europy. Zdaniem P. Skubiszewskiego ${ }^{94}$ przedmioty kultu napływały do państwa Piastów przede wszystkim z Niemiec jako dary dla katedry biskupiej lub fundacje książęce. Ich relikty są wymownym potwierdzeniem informacji zawartych w kronice Thietmara z Merseburga, Kosmasa z Pragi i Anonima tzw. Galla, pozwalając na wy-

89 Tamże, s. 350-351.

90 I. Gabriel, Christentum und Heidentum, [w:] Starigard/Oldenburg. Ein slawischer Herrschersitz des frühen Mittelalters in Ostholstein, red. M. Müller-Wille, Neumünster 1991, s. 279-297; por. s. 284-287.

91 V.H. Elbern, Das Beinkästchen im Essener Münsterschatz, Aachener Kunstblätter des Museumsvereins 44 (1973), s. 87-100; por. s. 96.

92 H. Kóčka-Krenz, Antyczna gemma z Ostrowa Tumskiego w Poznaniu, [w: ] Wielkopolska w dziejach. Archeologia o regionie, red. H. Machajewski, Poznań 2008, s. 231-236.

93 Ornamenta Ecclesiae. Kunst und Künstler der Romanik. Katalog zur Ausstellung des Schnütgen-Museums in der Josef-Haubrich-Kunsthalle, Köln 1985.

94 P. Skubiszewski, Katedra $w$ Polsce, s. 162, 164-165. 
sunięcie tezy, że tutejsze świątynie nie różniły się zasadniczo swym wyposażeniem od kościołów zachodniej Europy ${ }^{95}$.

Związki z kręgiem cywilizacji łacińskiej są uchwytne także poprzez znaleziska o świeckim charakterze - tłoka pieczętnego ${ }^{96}$, ołowianej bulli ${ }^{97}$ i stilusów/rylców do pisania na powoskowanych tabliczkach, świadczące o funkcjonowaniu kancelarii przy książęcej siedzibie. Studia historyczne nad początkami państwa piastowskiego pozwalają pośrednio wnioskować, że wkrótce po akcie chrztu zaistniało tu środowisko intelektualne związane z osobą biskupa Jordana, który jest uznawany za opiekuna pierwszego polskiego rocznika dworsko-kościelnego. Katedra poznańska musiała posiadać niezbędny w liturgii i nauczaniu księgozbiór, z którego do dziś zachowały się jedynie trzy kodeksy, dwa homiliarze i jeden ewangeliarz, pochodzące z XI w. Zapewne księgozbiór ten zawierał księgi liturgiczne, prawne, podręczniki i lektury szkolne do wykładania nauk wyzwolonych ${ }^{98}$. Można jedynie przypuszczać, że księgi te były dziełami skryptoriów zachodniej Europy przywiezionymi do państwa Piastów jako własność duchownych lub w charakterze darów.

Związki kulturowe z cesarstwem Ottonów skutkowały zmianami w organizacji przestrzeni tego ważnego politycznie i gospodarczo ośrodka, przekształconego z niewielkiego, jednoczłonowego gródka w czteroczłonową fortalicję z wyodrębnioną częścią książęcą, zabudowaną monumentalną architekturą świecką i sakralną. Wzorce dla ich bryl, struktury wnętrza i technik budowlanych - jak można sądzić - zostały zaczerpnięte z budowli zrealizowanych w zachodniej lub środkowej Europie. Wyposażenie części świeckiej poznańskiej rezydencji zapewne też nawiązywało do urządzeń palatiów zachodnioeuropejskich ${ }^{99}$. Nie znamy zasobu ksiąg niezbędnych w sprawowaniu liturgii, ale zapewne, sądząc po autorstwie kodeksu ofiarowanego Mieszkowi II przez księżną lotaryńską Matyldę ${ }^{100}$, należy także im przypisać pochodzenie z ośrodków zachodnioeuropejskich.

\footnotetext{
95 Tamże, s. 150-151.

96 A. Dębski, I. Marciniak, Średniowieczny tłok pieczętny, s. 161-168.

97 I. Dębska, A. Dębski, M. Sikora, Wczesnośredniowieczna pieczęć ołowiana, s. 99-110.

57 H. Kóčka-Krenz, Archeologiczne świadectwa o początkach szkolnictwa w Poznaniu, Kronika Miasta Poznania 4 (2001), s. 7-13.

98 B. Kürbis, Kultura wczesnego Poznania: twórcy, opiekunowie, uczestnicy, [w: ] Dzieje Poznania, t. I, red. J. Topolski, Warszawa - Poznań 1988, s. 101-133, por. s. 102.

99 H. Kóčka-Krenz, Wyposażenie palatiów w Europie Środkowej, Archaeologia Historica Polona 14 (2004), s. 11-27.
}

100 T. Michałowska, Literatura polskiego średniowiecza. Leksykon, Warszawa 2011. 
Śladem przenikania wytworów rzemiosła artystycznego na ziemie polskie poprzez zachodnią Europę jest tzw. kielich św. Wojciecha, którego czara była bizantyjskim agatowym pucharkiem z IX-X w. - jak przypuszcza P. Skubiszewski - darowanym przez Ottona III podczas jego pielgrzymki do grobu św. Wojciecha w Gnieźnie, wtórnie zaopatrzonym w złotą stopę z nodusem ${ }^{101}$. Biorąc pod uwagę uchwytne w źródłach archeologicznych elementy kultury świeckiej i sakralnej w poznańskim grodzie należy stwierdzić, że pierwsi piastowscy władcy czerpali wzorce dla swych realizacji z czołowych, znanych im ośrodków elitarnych środkowej Europy.

\author{
Prof. dr hab. Hanna Kóčka-Krenz \\ Wydział Archeologii \\ Uniwersytet im. Adama Mickiewicza w Poznaniu \\ ul. Uniwersytetu Poznańskiego 7 \\ 61-614 Poznań \\ e-mail: kockrenz@amu.edu.pl \\ Mgr Artur Dębski \\ Wydział Archeologii \\ Uniwersytet im. Adama Mickiewicza w Poznaniu \\ ul. Uniwersytetu Poznańskiego 7 \\ 61-614 Poznań \\ e-mail: mosmaiorum@onet.pl
}

Nadesłany: 15.09.2019

Nadesłany po poprawkach recenzyjnych: 14.05 .2020

Zaakceptowany: 15.05 .2020

\title{
Summary
}

The surveys of early medieval archaeological sites within Wielkopolska/Greater Poland and Kujawy/Cuiavia have provided numerous finds that reflect developed contacts between these areas and Northern Europe. They might be divided into two groups, i.e. "imports" and connections resulting from spirituality and beliefs. They have been recorded most frequently in hoards, while less commonly within settlements, strongholds, and in burials. Those traces

101 P. Skubiszewski, Tzw. Kielich św. Wojciecha - pamiątka Zjazdu Gnieźnieńskiego, [w:] Cultus et cognitio. Studia z dziejów średniowiecznej kultury, red. S.K. Kulczyński, Warszawa 1978, s. 521-536. 
of contacts with Scandinavia are more numerous in Wielkopolska/Greater Poland than in Kujawy/Cuiavia, and majority of those "imports" should be associated with the second stage of their appearance, dated to the second half of the $10^{\text {th }}$ and $11^{\text {th }}$ centuries.

West European influences on the culture of the elites in the first Piasts' state are visible in sociotopography of main fortified settlements, reflecting the structure of Carolingian and Ottonian residences, but also in a reception of forms of monumental architecture - both secular and sacral, including their furnishing. While considering cultural elements reflected in archaeological finds, it might be concluded that for their main implementations the first Piasts' rulers adapted models from the leading elite centres of Central Europe known to them.

Translated by: Lucyna Leśniak 